\title{
ORGANIZATIONAL ASPECTS OF SUSTAINABLE DEVELOPMENT IN URBAN PUBLIC TRANSPORT ENTERPRISES
}

\begin{abstract}
Grygorii Monastyrskyi $^{1}$, Tetiana Borysova ${ }^{2}$, Mariusz Barczak ${ }^{3}$
${ }^{1}$ Doctor of Science (Economics), Professor, Professor of the Department of Management, Public Administration and Personal, West Ukrainian National University, Ternopil, Ukraine, E-mail: grymon@ukr.net, ORCID: https://orcid.org/0000-0001-6694-1960

${ }^{2}$ Doctor of Science (Economics), Professor, Head of the Department of Marketing, West Ukrainian National University, Ternopil, Ukraine, e-mail: borisova.tanushka@gmail.com, ORCID: https://orcid.org/0000-00032906-2769

${ }^{3}$ Ph.D., Associate Professor, Vice-rector for organization and branches, University of Economy in Bydgoszcz,Bydgoszcz, Poland, e-mail: mariusz.barczak@byd.pl, ORCID: https://orcid.org/0000-0001$5270-6222$
\end{abstract}

Monitoring the growing role of the implementation of the sustainable development goals, on the one hand, and the use of the Internet of things in various spheres of life, on the other, is changing the way people think about their mobility. On the one hand, marketing support for sustainable development may at first glance seem somewhat premature when sustainable development and marketing management in national transport companies is under development. On the other hand, the ever-changing economic environment is forcing new approaches to address the social and environmental risks of enterprises and to ensure the effectiveness of sustainable development measures. Marketing support for sustainable development is a distinct area of business activity for an enterprise with marketing functions that ensure the effective design and implementation of sustainable development measures. That is why the organizing of marketing support of this process is relevant.

The results of the author's research confirmed the need for attention to the issues of urban transport development based on the principles of intellectual technologies in the marketing aspect. These issues are partly addressed in a series of projects by the Commission of the Council of Europe in support of energy-efficient transport, namely "A Direct Marketing Program for Public Transport (AD PERSONAM)", which lasted from 2008 to 2010, "Electric City Transport (ELE.C.TRA)", which lasted from 2013 to 2015, "Addressing Key Challenges of Sustainable Urban Mobility Planning (CH4LLENGE)", which lasted from 2013 until 2016. The era of projects focused on the development of urban transport began in the 1960-1970s. The works (Smeed, 1961; Buchanan, et al., 1964; Leibbrand, 1970; Schaeffer, Sclar, 1975) emphasize the role of municipal transport in accelerated urban development. Significant contribution to the development of conceptual role of municipal transport in accelerated urban development was made by Smeed [1] (outlined the traffic problem in town), Buchanan [2] (explained the applied aspects of traffic in towns), Leibbrand [3] (disclosed the questions of transportation and town planning), Schaeffer and Sclar [4] (highlighted the organizational aspects of urban transportation 
models and urban growth). In studies of scientists there is a lack of attention to the organizing of urban transport development and increase of its marketing support. Only some works of researchers highlights some aspects of the municipal transport's functioning, which is associated with its influence on cities innovation, tourist attractiveness (Zielinska, Barczak, 2019 [5]; Monastyrskyi, Borysova, 2018 [6]).

The purpose of this chapter is to develop methodological recommendations for marketing support for sustainable development measures at transport service providers.

\section{Institutional framework for sustainable development of urban public} transport enterprises. The implementation of the basic principles and objectives of marketing support for sustainable development measures in transport enterprises and objectives can only be achieved in an appropriate organizational manner, involving interaction between the sustainable development system and the marketing of enterprises. The aim of the study is to develop recommendations and approaches for the creation of organizational forms that would ensure an effective marketing process for sustainable development. Considering this we will use the term "organizing", as it more accurately expresses the purpose of the study than the term "organization", which is quite often used meaning a group of people whose activities are coordinated to achieve a certain goal (Kuz'min, Melnyk, 2003) [7].

The study of the scientific works of scientists (Spivakovska, Spivakovsky, 2014 [8]; Dembiński, 2018 [9]; Monastyrskyi, Borysova, 2018 [6]) has identified the following issues that need to be addressed consistently in the process of establishing an institutional framework for marketing support for sustainable development:

1. Organizational chart for sustainable development marketing support measures;

2. Determination of the level of centralization and decentralization of functions (delegation of authority);

3. Justification of the hierarchy;

4. Organization of effective information interactions;

5. Determining the number of employees (management standards);

6. Distribution of responsibilities between employees (division of labor);

7. Defining requirements for employees.

The conducted researches offer not only some generally accepted principles of development of organizational structures, but also such principles that should be used at the organizing of marketing maintenance of actions for sustainable development:

1. Resource justification of the organizing of marketing support of sustainable development measures. This principle involves considering the potential of marketing in the management of sustainable development when choosing an organizational form; 
2. The principle of taking into account the needs of the consumer. The organizational form must take into account the requirements and perceived risks;

3. Focus on the use of internal marketing support for sustainable development measures;

4. Continuous development of the system of measures for sustainable development and increase of marketing support of the specified measures;

5. Ensuring the adaptability of sustainable development measures to the external environment;

6. Ensuring the impact on external and internal factors of the enterprise;

7. The principle of continuous improvement. The development of organizational factors involves a change in the organizational form of marketing support for sustainable development;

8. The principle of gradual development of the organizational form of marketing support for sustainable development. It is expedient to adhere to this principle, given that it is not necessary to immediately strive for the optimal version of the organizational structure in order to overcome resistance to change;

9. The principle of scientific organization of marketing support for sustainable development. A necessary condition in the process of organizing the marketing of sustainable development activities is the use of scientific achievements in the field of organizing.

Successful marketing of sustainable development measures largely depends on how organizational issues are addressed. It is obvious that there should not be a single organizational structure within which this process would take place, but their typology should refer only to the most general fundamental decisions concerning the basic elements of the organizational structures, in order to take into account the most important factors affecting the process. Factors that should be the basis for the formation of the organizational structure of marketing support for sustainable development of the enterprise are as follows:

- enterprise size;

- activities diversification;

- owners, senior management, and employees' attitude to marketing and management of sustainable development;

- level of professional training of employees in marketing and sustainable development management;

- dynamics of the external environment;

- enterprise strategy;

- the level of structuring the problem, which requires measures for sustainable development; 
- the level of development of the system of measures for sustainable development of the enterprise;

- deadline for the formation of an event on sustainable development;

- marketing potential in the management of sustainable development of the enterprise;

- organizational culture of the enterprise.

Here we can see that the organization of marketing support for sustainable development activities in the enterprise depends on many factors. In the previous chapter, we substantiated the feasibility of taking into account the factors that mostly influence the choice of organizational form of marketing support for sustainable development measures:

1. The size of the enterprise;

2. Marketing potential in sustainable development management;

3. The level of development of the system of measures for sustainable development of the enterprise.

We will consider how approaches to the organization of marketing support of measures on sustainable development at the enterprise in the context of the factors offered above can be differentiated.

In medium-sized enterprises, the functions of marketing support for sustainable development measures should be assigned to the employee or department that performs the functions of marketing. According to research of the domestic scientists, the functions of marketing are often successfully performed by other departments.

According to our beliefs, it is inexpedient to create a separate structural unit in small enterprises to perform the functions of marketing support for sustainable development measures. The main argument of this conclusion should be considered that, first, specialization in a particular function is impractical in the absence of specialists to perform other marketing functions. Secondly, marketing support is a complex process that requires the use of all marketing tools, which will be easier to implement centrally with a small size of the enterprise.

If a company has marketing department, the functions of marketing support for sustainable development measures should be assigned to the head of the marketing department for the following reasons:

- marketing support for sustainable development measures provides decisions to reduce the risk of the enterprise. Thus, it requires that the person who makes decisions about this process, should belong to the influential management who makes decisions on core activities and measures for sustainable development;

- in the implementation of marketing support for sustainable development measures need to attract resources, which requires sufficient authority. 
In small enterprises, the issue of marketing support for sustainable development measures should be dealt with by the head or his deputy for commercial issues, as he usually performs the main functions of a sustainable development manager and marketing management functions. It is obvious that in this case the role of using external marketing measures for sustainable development of the enterprise significantly increases.

In large enterprises, where the marketing department operates, in order to perform the functions of marketing support for sustainable development measures, it is advisable to single out the position of sustainable development manager. At the same time, it is worth listening to the advice of marketing specialists that the optimal number of employees in the marketing department is within $10-15 \%$ of the list (Bratko, 1999) [10].

If the workload is high, a sustainable development manager is unable to perform his or her duties adequately. In this case, the staffing position should include the position of Assistant Sustainable Development Manager. This requires a clear division of responsibilities between them. The assistant should work with the sustainable development manager in special areas. Thus, if the sustainable development manager is a marketing specialist, the assistant of the sustainable development manager must be a sustainable development management specialist, analyst or specialist in other areas that require special knowledge. As an alternative or complement to the previous approach in large and medium-sized enterprises with a more organic organizational structure, marketing support for sustainable development activities can be performed by temporary groups, committees, commissions or interdepartmental meetings to address this process. Such integration presupposes the achievement of the goal - marketing support of sustainable development measures at the level of cooperation between individual structural units. Such temporary groups should include marketing specialists, decision-makers on sustainable development measures, economists, i.e. those key specialists involved in the development and implementation of sustainable development measures.

Depending on whether sustainable development measures are implemented at the enterprise, as well as how they are implemented (systemic or individual measures to reduce the level of risk), the organization of marketing support for these measures may have its own characteristics. For example, with a high level of development of a system of sustainable development measures, the structural unit for marketing these measures may be functionally subordinated to two heads - the head of the sustainable development management department (sustainable development manager) and the head of the marketing department (or unit that performs marketing functions). If the integrated indicator of the level of development of the system of sustainable development measures is lower than the integrated indicator of marketing potential in 
reducing the level of risk, the relevant structural unit should be subordinated to the marketing department or department that performs marketing functions at the enterprise.

Obviously, various functions of marketing support can be performed depending on the resource, organizational, methodological and other capabilities of the enterprise. For example, the significant potential of marketing in the management of sustainable development of the enterprise allows for a wide range of activities that will be reflected organizationally. With little marketing potential in sustainable development management, the range of possible measures will be narrowed. It is also obvious that the existing organizational structure of marketing largely determines the organizational form of marketing support for sustainable development measures, as it is necessary to take into account the organizational relations that have developed in the enterprise.

The potential of marketing in the management of sustainable development and the level of development of the system of measures for sustainable development are the factors that determine the limitations of the objectives of marketing support for sustainable development. The high potential of marketing in the management of sustainable development and the level of development of the system of measures for sustainable development creates opportunities for the implementation of the widest possible range of functions of marketing support.

At enterprises with high marketing potential in reducing the level of risk, favorable conditions are created for the organization of marketing support of these measures, and the functional responsibilities of the relevant structural unit may include the development of measures based on marketing methods to reduce social and environmental risk. sustainable development measures, ensuring the coordination of sustainable development measures with the needs and risks of target consumers, internal marketing, as well as marketing risk management.

At the average level of development of the system of measures for sustainable development and marketing potential in the management of sustainable development, the functional responsibilities of employees are somewhat limited, in particular, they are determined by specific features of the marketing system of the enterprise and its marketing potential.

Given the low level of development of the system of sustainable development measures and the potential of marketing in sustainable development management, it is advisable to include monitoring in the mandatory types of marketing support for sustainable development measures. In this case, it is not necessary to transform the organizational structure of enterprise management, it is necessary to expand the range of responsibilities of the employee or employees who are entrusted with the functions of marketing research and (or) marketing analytical function. 
The organizing of marketing support for sustainable development measures is significantly influenced by the organizational features of marketing structures of the enterprise. The essence, advantages, and disadvantages of the main organizational forms of marketing management are quite fully set out in domestic and foreign literature. However, the issue of positioning the function of marketing support for sustainable development measures in various organizational structures of marketing management has not been studied. Before addressing this issue, we will consider the distribution of functions and tasks of marketing support for sustainable development measures between the central and local structural units. The following conclusions are valid for those enterprises in the structure of which it is advisable to distinguish these structural units.

At the level of the central structural unit for marketing support of sustainable development measures, the following main tasks can be performed:

- creation of organizational preconditions for the implementation of marketing support for sustainable development activities at the enterprise;

- integrated presentation of reporting information on marketing support for sustainable development and marketing risk management to the top management;

- support and coordination of the process of selection of marketing support of these measures in accordance with the objectives of sustainable development of the enterprise and existing constraints.

The tasks of marketing support for sustainable development measures at the local level should primarily include the following:

- planning, implementation, control, adjustment of marketing support for sustainable development measures;

- development of information system of marketing support;

- ensuring the consistency of activities with the needs of target customers;

- submission of a report to the head (central manager for sustainable development or a person who performs his duties).

The issue of interaction between the central and local sustainable development manager remains important. The main aspect of the interaction of the central and local structural unit is to report on the current results of marketing support for sustainable development measures. In turn, the local structural unit can receive the necessary information about changes in the system of measures for sustainable development, the environment of the enterprise, and the goals of the enterprise.

Features of marketing support for sustainable development of urban public transport enterprises. Besides, we will consider the options for organizational structures of marketing support for sustainable development, based on basic organizational forms of marketing management. The functional scheme of marketing support for sustainable development activities with the separation of the position of 
sustainable development manager is appropriate in enterprises where the functional structure of marketing is successful with the decentralization of operational management of marketing. The role of the central manager for sustainable development is performed by the head of the marketing department, and the role of the local manager is performed by the manager for sustainable development, if necessary, the position of assistant manager for sustainable development can be singled out. At the same time, the establishment of interaction with other functional units plays an important role.

The Sustainable Development Manager provides marketing support for sustainable development activities, its planning, organization, implementation and monitoring, evaluates the effectiveness, selects marketing support, forms an archive of activities, reports to the head of the marketing department. In case of larger-scale sustainable development activities, the intensity of functional interaction with other departments and the head of the marketing department also increases.

For small enterprises, it is advised to entrust the functions of a sustainable development manager to the owner of the enterprise or manager. Additionally, it is important to attract external support, including the services of marketing firms.

In large enterprises, with such marketing organizational structures as goods (product), regional, market (consumer-oriented) based on differentiation on a certain basis, it is advisable to single out as the central structural unit of the chief manager for sustainable development and local sustainable development manager in the structure of a separate local unit. This can be done in the form of a position of sustainable development manager of a separate divisional unit or these functions can be assigned to a marketer or head of marketing department.

In case of product and functional (product-functional) scheme of organization of marketing support of sustainable development measures, the sustainable development manager is linearly subordinated to the head of the marketing department, and he, in turn, is the functional head of employees of local marketing departments, which perform the functions of marketing support for sustainable development activities.

The generalization of the experience of the division of power between top and lower level management and our own research allow us to suggest the following key responsibilities of the central manager for sustainable development:

- development of forms of collecting analytical information in terms of divisions (offices);

- collection of specific information on sustainable development;

- selection of a comprehensive program of marketing support for sustainable development measures;

- evaluating the effectiveness of the program of marketing support for sustainable development measures; 
- forecasting the reduction of the level of social and environmental risk due to the use of marketing support for sustainable development measures;

- providing recommendations on marketing solutions for sustainable development measures.

The main responsibilities of the local sustainable development manager should include the following:

- monitoring information in the division;

- processing and analysis of the received data;

- development of proposals for marketing support for sustainable development in the division;

- assessment of the feasibility of marketing support for sustainable development measures;

- evaluation of options for marketing support of sustainable development measures;

- substantiation of expenses for marketing support of measures for sustainable development in the division.

The organizational forms of marketing support for sustainable development measures discussed above certainly have some drawbacks. It is obvious that the obstacle to the implementation of an effective process may be poor communication with other structural units of an enterprise. This shortcoming is eliminated by using a matrix organizing scheme, which provides for the separation of a special working group, which includes employees needed to address the issue of marketing support for sustainable development measures in each situation. This group is engaged in the development of sustainable development measures, including the formation and implementation of marketing support for these measures. The Sustainable Development Manager or the employee in charge of marketing support for sustainable development activities interacts functionally with the Central Sustainable Development Manager or the Head of the Marketing Department on various issues that may relate to obtaining additional information, reporting, methodological or resource support, and coordination. A company may not have a sustainable development workforce, which is quite common for national transport companies. The schemes under consideration may serve as the basis for an organizational form of marketing support for the sustainable development of a particular enterprise.

The distribution of tasks, rights and responsibilities in this area between the various structural units involved is essential for the organizing of marketing support for sustainable development measures. An important element of organizing the process of marketing support for sustainable development is the organization of effective information interactions. Information exchange related to this process is to 
provide prompt, reliable, and complete information at specified intervals and involves the following procedures:

- collection of information on the current state of the object of influence (marketing potential in the management of sustainable development and measures for sustainable development);

- analysis of the received information and comparison of the current state with the desired one;

- development of measures of managerial influence in order to transform the potential of marketing in the management of sustainable development, measures for sustainable development in the desired state;

- transfer of managerial influence of the object of influence.

The process of marketing sustainable development activities involves feedback, which allows anyone to determine the effectiveness of management influence. It is obvious that for each type of marketing support for sustainable development measures, information processes will differ in content. Given the peculiarities of the formation and implementation of these types of marketing support, information exchange should include the following procedures:

Monitoring:

- collection and analysis of information about the conditions of operation of the enterprise;

- documentation of monitoring results;

- bringing the gathered information to the manager of sustainable development or the person who performs his functions, to make a decision on corrective action;

- obtaining and analyzing information on the progress of the use of monitoring results.

Marketing methods of sustainable development:

- collection and analysis of information on sustainable development measures, deadlines for their implementation, and the level of environmental friendliness of the enterprise;

- collection and analysis of information about the conditions of operation of the enterprise;

- collection and analysis of information on the potential of marketing in the management of sustainable development and the level of development of sustainable development measures;

- documenting the decision on marketing activities aimed at sustainable development, and bringing them to the performers;

- providing the necessary information to the executors for further adjustment of sustainable development measures; 
- obtaining and analyzing information on the implementation of marketing support for sustainable development measures;

- formation of a bank of marketing methods.

Marketing solutions for sustainable development measures:

- collecting and obtaining information about the problem during the implementation of measures for sustainable development and the formation of relevant tasks;

- documentation of proposals for marketing decisions on sustainable development measures;

- bringing information about the decision to the executors (sustainable development manager or persons who perform the functions of sustainable development management of the enterprise);

- collection and analysis of information on the results of the decision.

Ensuring consistency of sustainable development measures with the needs and risks of target consumers:

- collection and analysis of information on sustainable development measures;

- collection and analysis of information about the needs and risks of target consumers;

- collection and analysis of information about the available marketing potential in the management of sustainable development of the enterprise;

- documentation of recommendations aimed at aligning sustainable development measures with the needs and risks of target consumers;

- bringing information about the decision to the executors;

- collection and analysis of information on the results of the decision.

Internal marketing:

- collection and analysis of information on the implementation of relevant marketing functions by individual departments and employees;

- collection, processing and analysis of information on available material, financial and other resources to determine areas of internal marketing;

- bringing the received information to the head for the purpose of making the decision on adjustment of actions;

- obtaining information on the progress and results of the implementation of the decision.

As for the requirements for candidates for the position of sustainable development manager, it is best to choose among the employees of the marketing department or sales department of the enterprise. This is due to the need to be aware of the threats and opportunities of the company in the market, to influence the marketing potential of the company, and to have skills in organizing marketing events. It is necessary to conduct an introductory seminar or training, the purpose of 
which is to get acquainted with the basics of sustainable development management, as well as the specifics of risks and measures for sustainable development of a particular enterprise. In the field of sustainable development management, a candidate for the position of a sustainable development manager must be familiar with the terminology of risk, sustainable development, risk factors, classification of environmental risks, be able to perform quantitative risk analysis, predict the consequences of financial risk, have expert procedures and risk assessment methods and risk lowering methods.

The recommended approaches to marketing support for sustainable development facilitate the identification and selection of the organizational form of the process. However, the final decision on the organizational form should be made only after a comparison of the quantitative criteria for the choice of an organization. Further research is aimed at quantifying selection criteria, such as the economic, organizational and social effectiveness of marketing support for sustainable development. The sustainable development manager or the person entrusted with his functions must meet the general requirements for staff: high moral qualities, analytical skills, ability to think holistically, conciseness and literacy in business communication, the ability to defend their own point of view, and cooperate, and good social skills. In addition to the listed qualities, candidates for this position must meet a number of specific requirements due to the specifics of the manager of sustainable development position: have sufficient knowledge in the field of sustainable development management, know its terminology, be able to implement operational and strategic marketing measures, have good computer skills. In terms of qualifications, this requires an economic background in education, professional experience and marketing skills. The specifics of the work require additional knowledge, so it is necessary to regularly improve skills through special courses, trainings, as well as independently by studying special literature on sustainable development management and marketing.

\section{References:}

1. Smeed R., J. (1961). The Traffic Problem in Town. Manchester, 220 p.

2. Buchanan C., (1964). Traffic in Towns, London, 22 p.

3. Leibbrand K., (1970). Transportation and Town Planning, Cambridge, $34 \mathrm{p}$.

4. Schaeffer K., Sclar E., (1975). Access for All: Transportation and Urban Growth. Hammondsworth 1975, s. 123

5. Borysova T., Monastyrskyi G., Zielinska A., Barczak M., (2019). Innovation Activity Development of Urban Public Transport Service Providers: Multifactor Economic and Mathematical Model. Marketing and Management of Innovations, № 4, 98 p.

6. Borysova T., Monastyrskyi G., (2018). Marketing innovation activity of urban public transport: results of the empirical study. Marketing and Management of Innovations, Sumy, № 3, 229 p.

7. Kuz'min O., Melnyk O., (2003). Teoretychni ta prykladni zasady menedzhmentu, Lviv, 352 p.

8. Spivakovska T., Spivakovsky S., (2014). Using Marketing Tools in the Ukrainian Automobile Market. Formation of Market Relations in Ukraine, № 7, 59 p. 
9. Dembiński P., (2018). The outlook for the development of the electric car market in Poland until 2025 compared to the Norwegian market. Research Papers in Economics and Finance, № 2, 19 p.

10.Bratko O., (1999). Orhanizatsiya marketynhovoyi diyal'nosti na pidpryyemstvi, Ternopil, s. 26

11.Schüßler M., Niels T., Bogenberger K., (2017). Model-based Estimation of Private Charging Demand at Public Charging Stations. EJTIR, № 17(1), 153 p. 